\title{
STUDIES OF ECOTOXICITY OF HERBICIDES TO INFLUENCE THE SOIL FAUNA
}

\author{
Khyzhnyak Svitlana*, Sterlikova Oksana, Poloschyk Sergiy, \\ Bulanchuk Yuliya, Samkova Oksana
}

National University of Life and Environmental Sciences of Ukraine, Kyiv, Ukraine

\section{ДОСЛІДЖЕННЯ ЕКОЛОГІЧНОЇ ТОКСИЧНОСТІ ГЕРБІЦИДІВ ЗА ЇХ ВПЛИВОМ НА ГРУНТОВУ ФАУНУ
Хижняк Світлана, Стерлікова Оксана, Поліщук Сергій, Буланчук Юлія, Самкова Оксана

The study of the ecotoxicity of post-emergence and pre-emergence herbicides, which are related to organochlorine pesticides, was carried out. The test objects of the soil fauna were used, since the regulation of the safe use of plant protection products requires an examination of their influence on the soil biota. During the laboratory biotesting the representatives of soil invertebrates - earthworms Eisenia fetida, which play an important role in soil-forming processes, were used as the test object. The changes of the functional status of soil microorganisms (the number of basic taxonomic, ecological, trophic and physiological groups of microorganisms, the biomass of soil microorganisms, the potential nitrification ability of the soil) were also monitored. Differences in the ecotoxicity of herbicides A, CE (active ingredient - acetochlor, $900 \mathrm{~g} / \mathrm{l}$ ) and K, RK (active ingredient - clopyralid, $300 \mathrm{~g} / \mathrm{l}$ ) were revealed in terms of the median lethal concentration $\left(\mathrm{LC}_{50}, 14\right.$ days) for a representative of soil mesofauna Eisenia fetida and the effects on soil microorganisms. The preparation A (a.i acetochlor) according to a defined value of the median lethal concentration which is $479 \mathrm{mg} / \mathrm{kg}$ of substrate (under artificial substrate conditions) for the use of Eisenia fetida is classified as slightly toxic (hazard class III). The obtained results allow to assume the potential ecological risks for the stable functioning of the microbiocenosis with the use of the preparation $\mathrm{A}$ (a.i. acetochlor) in conditions of a typical black soil. When using the preparation $\mathrm{K}$ (a.i. clopyralid) there is no effect on the survival rate of Eisenia fetida. There are also no significant changes in the quantitative-group composition of the microbial cenosis under conditions of dark gray soil and the typical black soil, no changes in the index of the total biomass of the metabolically active pool of microorganisms and the potential of nitrate accumulation. This indicates its safety in compliance with the recommended application rates. Attention is focused on the high content of the active substance of herbicide A (a. i. acetochlor), compared with $\mathrm{K}$ (a.i. clopyralide), its use as an emulsion concentrate, which, along with the proposed high pesticide load, creates potential environmental risks of this preparation for soil fauna.

Keywords: agroecosystem; pesticide; ecotoxicity; soil fauna; test-objects

*Corresponding author: Svitlana Khyzhnyak, National University of Life and Environmental Sciences of Ukraine, Kyiv, Ukraine, $\bowtie$ khs2014@ukr.net 


\section{Вступ}

Агроценози - штучні екосистеми, які створюються та контролюються людиною, та, на відміну від природних екосистем, не відрізняються видовим різноманіттям. Як правило в них культивується певний вид рослин, а з іншими видами борються шляхом використання пестицидів. Очевидним $\epsilon$ факт загрози цих препаратів не лише для видів-мішеней, але як для корисних культур (Butani and Shukla, 1994; Arif and Vahidy, 1996; Танский, 1998) так і агроценозу в цілому (Харина, 2000).

У зв'язку з цим проведення досліджень з визначення токсичності пестицидів, залишається актуальним напрямком прикладної екології. В даному аспекті регламентація безпечного використання засобів захисту рослин, окрім дослідження фітотоксичності, потребує експертизи їх впливу на ґрунтову біоту. Типовими представниками ґрунтових безхребетних $\epsilon$ земляні черви Eisenia fetida, для яких грунт - це середовище для існування, росту і розвитку. Відіграючи важливу роль у грунтоутворюючих процесах, ці організми $\epsilon$ чутливими індикаторами змін стану середовища існування, що дозволяє використовувати їх як тест-об'єкти при проведенні біотестування (Танский, 1998; Харина, 2000). Крім того, при обґрунтуванні екологічної безпечності агровиробничого застосування хімічних препаратів важливо визначити їх вплив на мікробні ценози ґрунту, відслідковувати зміни функціонального статусу ґрунтових мікроорганізмів.

Мета даної роботи - порівняльне дослідження екотоксичності гербіцидів різних хімічних груп та препаративних форм за їх впливом на грунтову фауну.

\section{Матеріали та методи}

Вплив препаратів на мікробні ценози ґрунту оцінювали за наступними показниками:

1. чисельність основних таксономічних, еколого-трофічних та фізіологічних груп мікроорганізмів;

2. біомаса ґрунтових мікроорганізмів (ДСТУ 14240-2:2003);

3. потенційна нітрифікаційна здатність ґрунту (ДСТУ ISO 14238:2003).

Для проведення мікробіологічних аналізів відбирали наважки ґрунту (маса 300 г), зволожували до 65 - 70 \% повної вологості, з метою стабілізації мікробіологічних процесів, та компостували протягом 3 діб, а потім обробляли водним розчином досліджуваного препарату. Контролем слугував відповідний тип ґрунту зволожений еквівалентним об'ємом стерильної дистильованої води. Дослідні і контрольні зразки компостували протягом 14 діб. Після інкубації визначали чисельність основних таксономічних, фізіологічних та еколого-трофічних груп та активність біологічних процесів ґрунту.

Для визначення чисельності ґрунтової мікробіоти проводили висів ґрунтової суспензії на агаризовані поживні середовища (Звягинцев, 1991). Кількість мікроорганізмів виражали в колоній-утворюючих одиницях (КУО) на один грам абсолютно сухого ґрунту з урахуванням коефіцієнту вологості та розведення ґрунтової суспензії.

Досліджували поведінкову реакцію Eisenia fetida та визначали ( $\mathrm{LC}_{50}, 14$ діб) препаратів за показником відсотку смертності червів із застосуванням штучного субстрату згідно (ДСТУ ISO 11268-1:2003). Тестовими об'єктами слугували дорослі статевозрілі особини ґрунтових червів Eisenia fetida, віком від 2 місяців, вагою від 300 до 500 мг. Штучний субстрат наступного складу: тонко розмелений сфагновий торф - $10 \%$; каолінова глина - $20 \%$; промисловий кварцовий пісок - 70 \% вмісту на суху масу. Субстрат готували за добу до початку досліджень. Субстрат загальною масою 500 г (за сухою речовиною) поміщали у скляний контейнер місткістю 2 дм ${ }^{3}$ та перемішували з розчинами препаратів у відповідних концентраціях. Контрольним варіантом слугував штучний субстрат зволожений дистильованою водою. Надалі у кожному з контейнерів розміщували по 10 особин тест-об'єктів Eisenia fetida. Дослід проводили у чотирьохкратній повторності, його тривалість становила 14 днів. 
Об'єктом дослідження слугували сучасні препарати:

1. гербіцид A, KE (діюча речовина - ацетохлор, 900 г/дм³ $)^{3}$ - концентрат емульсії, селективний досходовий гербіцид, який використовується шляхом внесення до грунту, для знищення однорічних одно- і дводольних бур'янів на посівах сої, кукурудзи, соняшнику. Максимальна норма витрат 2,0 - 3,0 дм³ /га при однократній обробці;

2. гербіцид К, РК (діюча речовина - клопіралід, 300 г/ дм³ ) - розчинний концентрат, системний післясходовий гербіцид з високою активністю по відношенню до бур'янів, стійких до арилоксиалканкарбонових кислот та їх похідних, а також вибірковістю по відношенню до зернових, культур родин крестоцвітних, льону та цукрових буряків. Поглинається рослинами як листям та корінням, так, можливо, лише листям (Куликова, 2010). Максимальна норма витрат 0,5 дм³/га при однократній обробці.

Робочі розчини препаратів готували безпосередньо перед експериментом.

Для обробки первинних результатів досліджень використовували статистичні методи аналізу із застосуванням стандартного пакета програми MS Excel. Визначення половинної медіанної летальної концентрації ( $\left.\mathrm{LC}_{50}\right)$ препарату здійснювали з використанням методу пробіт-аналізу (Платонов, 2010).

\section{Результати та їх обговорення}

Проведено дослідження впливу гербіциду А (д.р. - ацетохлор) в концентраціях 200, 400, 600, 800 та 1000 мг/кг субстрату на черви за досліджуваними показниками. Спостереження за поведінковими реакціями особин показали, що за концентрації препарату 200 мг/кг субстрату будь-яких змін не відбувається. Черви були рухливі та однаково реагували як на світлове, так і на механічне подразнення. При концентраціях препарату від 400 мг/кг субстрату та вище черви на початку досліду не заривалися в субстрат протягом 2 - 3 год, повзали по поверхні субстрату абобули скручені в клубок. На 7 день експозиціїза концентрації препаратувід 400 мг/кг субстрату і вище спостерігалось зниження рухливості червів, загальмованість їх реакції на світлове і механічне подразнення. Крім того, за концентрації 600 мг/кг субстрату спостерігалась $17,5 \pm 0,3 \%(P<0,05)$ загибель тест-організмів, а за концентраціях 800 та 1000 мг/кг субстратів відмічена 100 \% загибель організмів. На 14 день експозиції спостерігалась 65,5 $\pm 0,4 \%(P<0,05)$ та $57,2 \pm 0,3 \%(P<0,05)$ загибель тест-організмів за концентраціях препарату 400 та 600 мг/кг субстрату відповідно.

Визначена величина медіанної летальної концентрації ( $\mathrm{LC}_{50}$ ) на 14 добу експозиції становить 479 мг/кг. Згідно класифікації (Руководство по классификации экологической опасности пестицидов, 2010) досліджуваний препарат за використання тест-організмів належить до слаботоксичних (клас небезпечності III).

Аналогічно проведено дослідження впливу гербіциду К (д.р. клопіралід) в концентраціях 10, 100 та 1000 мг/кг субстрату на черви. Спостереження за поведінковими реакціями дослідних особин показали, що на початку досліду, як і в контрольному варіанті, черви не заривалися в субстрат протягом 15 - 20 хв. На 7 день експозиції у всіх дослідних та контрольній групах загибелі тест-організмів або інших змін не було виявлено. На 14 день експозиції загибелі тест-організмів не було виявлено, черви реагували на механічне та світлове подразнення, як у контрольному варіанті. Тобто негативного впливу на поведінкові реакції червів не виявлено.

Визначена величина медіанної летальної концентрації ( $\left.\mathrm{LC}_{50}\right)$ за 14 діб експозиції була більшою за 1000 мг/кг субстрату. Згідно класифікації (Руководство по классификации экологической опасности пестицидов, 2010) за використання тест-організмів, досліджуваний препарат належить до практично нетоксичних та малонебезпечних препаратів (клас небезпечності IV). 
Дослідження функціонування мікробного ценозу грунту - $\epsilon$ одним з діагностичних критеріїв оцінки його екологічного стану та родючості, а з іншого боку використовується для оцінки екотоксичності гербіцидів. В роботі досліджували чисельність основних таксономічних, фізіологічних та еколого-трофічних груп ґрунтових мікроорганізмів (амоніфікуючі, амілолітичні, педотрофні, оліготрофні, фосформобілізуючі, актиноміцети, міксоміцети).

За впливу препарату А (д.р. ацетохлор) спостерігали токсикологічний вплив щодо мікроміцетів та оліготрофних мікроорганізмів в умовах чорнозему типового, чого не спостерігали в умовах темно сірого ґрунту. Для препарату К (д.р. клопіралід) не виявлено впливу на чисельність основних таксономічних, фізіологічних та еколого-трофічних груп ґрунтових мікроорганізмів в умовах чорнозему типового та темно-сірого грунту.

Один з важливих показників активності мікробіологічних процесів - продуктивність ґрунтових мікроорганізмів. Мікробна біомаса має надзвичайне значення у процесах колообігу речовин та енергії, геохімічних перетвореннях елементів у трофічних ланцюгах. За отриманими результатами впливу препарату А (д.р. ацетохлор) біомаса мікроорганізмів знижується на 12 \% відносно контролю в умовах чорнозему типового. Для препарату К (д.р. клопіралід) не виявлено впливу на біомасу мікроорганізмів (табл. 1).

Таблиця 1 Показники екотоксичності гербіциду А (д.р. ацетохлор, 900 г/л) та К (д.р. клопіралід, 300 г/л) за впливу на грунтову фауну

Table 1 Indices of ecotoxicity of herbicides A (a.i acetochlor, $900 \mathrm{~g} / \mathrm{l}$ ) and K (a.i. clopyralid, $300 \mathrm{~g} / \mathrm{l}$ ) by their influence on soil fauna

\begin{tabular}{|c|c|c|}
\hline Варіант досліду & $\begin{array}{c}\text { А, KE (д.р. ацетохлор, } \\
900 \mathrm{r} / \mathrm{gm}^{3} \text { ) }\end{array}$ & $\begin{array}{c}\text { K, КС (д.р. клопіралід } \\
300 \text { г/дм³) }\end{array}$ \\
\hline $\begin{array}{l}\text { Медіанна летальна концентрація } \\
\text { (LC }{ }_{50}, 14 \text { діб) для Eisenia fetida }\end{array}$ & 479 мг/кг субстрату & >1 000 мг/кг субстрату \\
\hline \multicolumn{3}{|c|}{ 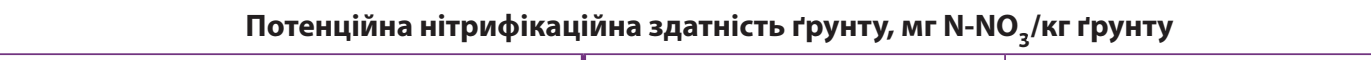 } \\
\hline $\begin{array}{l}\text { В умовах чорнозему типового } \\
\text { Контроль } \\
\text { Дослід } \\
\text { В умовах темно-сірого грунту } \\
\text { Контроль } \\
\text { Дослід }\end{array}$ & $\begin{array}{c}96,7 \pm 24,51 \\
247,7 \pm 37,15^{*} \\
\\
127,6 \pm 19,15 \\
126,5 \pm 18,98 \\
\end{array}$ & $\begin{array}{l}128,6 \pm 17,15 \\
126,5 \pm 18,18 \\
126,6 \pm 18,05 \\
125,1 \pm 18,76\end{array}$ \\
\hline \multicolumn{3}{|c|}{ Біомаса ґрунтових мікроорганізмів, мкг С/г сухого ґрунту } \\
\hline $\begin{array}{l}\text { В умовах чорнозему типового } \\
\text { Контроль } \\
\text { Дослід } \\
\text { В умовах темно-сірого грунту } \\
\text { Контроль } \\
\text { Дослід }\end{array}$ & $\begin{array}{c}252,9 \pm 13,56 \\
221,8 \pm 6,80^{*} \\
75,2 \pm 0,10 \\
70,8 \pm 3,17\end{array}$ & $\begin{array}{c}253,1 \pm 13,50 \\
248,7 \pm 6,80 \\
70,2 \pm 0,14 \\
73,3 \pm 3,11\end{array}$ \\
\hline
\end{tabular}

Нітрифікаційна здатність ґрунту, яка $€$ об'єктивним показником впливу хімічних препаратів на ступінь ґрунтової родючості, за впливу препарату А (д.р. ацетохлор) знижується на 17 \% відносно контролю в умовах чорнозему типового.

Таким чином, отримані результати дозволяють припустити потенційні екологічні ризики для стабільного функціонування мікробоценозів при застосуванні препарату А (д.р. - ацетохлор) в умовах чорнозему типового. На фоні застосування препарату К (д.р. клопіралід) не відбувається істотних зрушень кількісно-групового складу мікробного ценозу досліджуваних 
ґрунтів, показника загальної біомаси метаболічно активного пулу мікроорганізмів та потенціалу нітратонакопичення, що свідчить про його безпечність при дотриманні рекомендованих норм внесення.

При використанні пестицидів необхідно враховувати їх препаративні форми та рекомендовані норми витрат. Зокрема А (д.р. ацетохлор) використовують у вигляді концентрату емульсії (KЕ), препаративна форма, що містить 90 \% діючої речовини, а також розчинники та емульгатори. Внаслідок високої концентрації препарат здатен викликати пошкодження рослин, він легко проникає крізь шкірутварин, зокрема епідерміс шкіри червів чи їх травний канал, що призводить до прояву токсичної дії. Препарат К (д.р. клопіралід) - розчинний концентрат (РК), що містить 30 \% діючої речовини. Згідно рекомендованої максимальної норми внесення використання гербіциду А (д.р. ацетохлор) обумовлює більше пестицидне навантаження у порівнянні з К (д.р. клопіралід).

\section{Висновки}

Порівняльне дослідження екотоксичності досходового А, KЕ (діюча речовина - ацетохлор, 900 г/дм³ $)$ та післясходового К, РК (діюча речовина - клопіралід, 300 г/дм³) гербіцидів, які належать до хлорорганічних пестицидів, показало відмінності за їх впливу на тест-організми представників грунтової фауни (мікроорганізми та грунтові черви). Отримані результати дозволяють припустити потенційні екологічні ризики гербіциду А, KE (діюча речовина ацетохлор, 900 г/дм³ ) для грунтової фауни.

\section{Література}

Arif, M., Vahidi, A.A. 1996. Toxicity of fungicides Nimrod and Dithane M-45 on mitotic cells of Allium cepa L. Phillip. J. Sci., vol. 125, no. 4, p. 271-289. ISSN 0031-7683.

Butani, J.V., Shukla, P.T. 1994. Cytological effects of pesticides on onion (Allium cepa L.) root tip Gujarat. Agr. Univ. Res. J, vol. 20, no. 1, p. 60-65. ISSN 0250-5193.

ДСТУ 14240-2:2003. Якість грунту. Визначення грунтової мікробної біомаси. Частина 2: Фумігачійноекстракційний метод. 2004. К.: Держспоживстандарт України. 8 с.

ДСТУ ISO 14238:2003. Якість ґрунту. Біологічні методи. Визначання мінералізачії азоту і нітрифрікації в грунтах та впливу хімічних речовин на чі прочеси. 2004. К.: Держспоживстандарт України. 8 с.

ДСТУ ISO 11268-1:2003 (ISO 11268-1:1993, IDT). Якість грунту. Вплив забрудників на земляних черв'яків (Eisenia fetida). Частина 1. Визначання гострої токсичності з використанням штучного субстрату. 2004. К.: Держспоживстандарт України. 8 с.

Куликова, Н.Ф. 2010. Гербициды и экологические аспекты их применения. М.: Книжный дом «ЛИБРОКОМ». 152 с. ISBN 978-5-397-01431-1.

Методы оценки экологической безопасности пестицидов при их регистрации (Руководство по классификации экологической опасности пестицидов). 2010. Большие Вяземы. 14 с.

Методы почвенной микробиологии и биохимии. Под ред. Д.Г. Звягинцева. 1991. М.: Изд. МГУ. 304. ISBN 5-211-01675-0.

Платонова, А.Г. Ахалая, М.А. 2010. Применения метода пробит-анализа в радиобиологии. Расчет полулетальной дозы ЛД50. М.: НИЯУМИФИ. 36 с.

Таинский, В.И., Логинова, Л.Н., Солдатова, Н.К. 1998. Влияние инсектицидов на некоторые физиологоморфологические показатели и продуктивность зерновых культур. Агрохимия, № 5, с. 79-85. ISBN 0002-1881.

Харина, С.Г. 2000. Воздействие интенсивного применения средств химизации на агроэкосистемы Верхнего Приамурья. Агро, т. XXI, № 7, с. 17. 